\title{
鞉底に歩行補助を目的とした加エを施した婦人靴の着用が 歩行姿勢に与える影響
}

○村野 良太, 友野 貴之 (早稲田大学人間科学学術院),

佐藤 健 (実践女子大学生活科学部), 松山 智佳 (早稲田大学大学院人間科学研究科),

市川 寛子, 豊田 真実（株式会社プリーズ）,

加藤 麻樹 (早稲田大学人間科学学術院)

Effect of Wearing Women's Shoes with Soles Modified for Walking Aid on Walking Posture

Ryota MURANO, Takayuki TOMONO (Waseda University, Faculty of Human Sciences),

Takeshi SATO (Jissen Women's University, Faculty of Human Life Sciences),

Chika MATSUYAMA (Waseda University, Graduate School of Human Sciences),

Hiroko ICHIKAWA, Makoto TOYODA (Please Co.,Ltd)

Macky KATO (Waseda University, Faculty of Human Sciences)

\section{1.はじめに}

職場で着用される婦人靴は一般的に外見が重視 され，“歩きやすさ”については優先順位が低く なる傾向にある．歩きやすさの優先順位が低い靴 を着用し続けることで足部の疲労や痛みを引き起 こす恐れがある．近年では，日本の職場で女性が ハイヒールおよびパンプスの着用を義務づけられ ていることに抗議する社会運動が起きている.

見かけを損なわず，かつ歩きやすさを向上させ， 外見と歩行補助機能を両立させるといったコンセ プトのもとla veritaと呼ばれるパンプスが開発さ れた. la veritaは一般的なパンプスと比較し，靴 底に歩行を補助する機能として，つま先側に3本 の棒状のゴム（以下，アシストブルーバー）が施 されている.

本研究はla veritaと一般的なパンプスとを着用 させた際の歩行姿勢を評価し，アシストブルー バーの歩行補助効果について明らかにすることを 目的とする.

\section{2. 方法}

実験参加者は日頃からパンプスを着用する女性 102名（45.3 \pm 14.1 歳）とした。課題動作は自然歩 行とした. 歩行路は $10 \mathrm{~m}$ と, 屋内施設で実施し た。着用寸る靴の条件はla verita と統制用のパン プスとした。なお，統制用のパンプスはla verita と同様の形状をし，アシストブルーバーが施され ていないものとした. 各条件について1試行ずつ 実施した。歩行姿勢の計測にはMVP-WS2-S

（Microstone社）を使用した。 センサを被験者の 上部体幹（以下，Th6）と下部体幹（以下，S2）

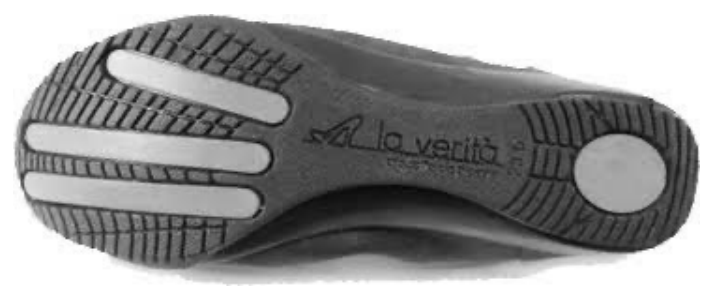

図1 la veritaの底面

に取り付けた．分析項目は，Th6，S2それぞれの 歩行周期3周期分の平均動摇量（左右，上下，前 後), 平均軌跡長 (水平面, 前額面, 矢状面), 歩 行周期時間, 着地時の衝撃（左右）とした.

\section{3. 結果}

実験参加者102名のうち，ノイズが混入した データを示した36名分のデータを除外し，66名分 のデータを用いて分析を行なった. 各分析項目に ついて，対応のある $t$ 検定を行なった。 その結果， 上下動摇量 $(\mathrm{S} 2) \quad(t(65)=2.92, p<.01)$, 歩行周 期時間 $(t(64)=3.09, p<.01)$, 着地時の衝撃 （左） $(t(64)=2.47, p<.05 ）$ において有意差が認 められた (図2).

統制靴条件と比較し, la verita条件では下部体 幹の上下動摇量が有意に大きいことがわかった. また，有意な差は認められなかったが，上部体幹 の上下動摇量および，前額面軌跡長と矢状面軌跡 長といった上半身の上下方向に関連する動きが大 きかった（図2，3）。また，統制靴条件と比較し， la verita条件では歩行周期時間は短く, 着地時の 衝撃（左）は大きかった. 

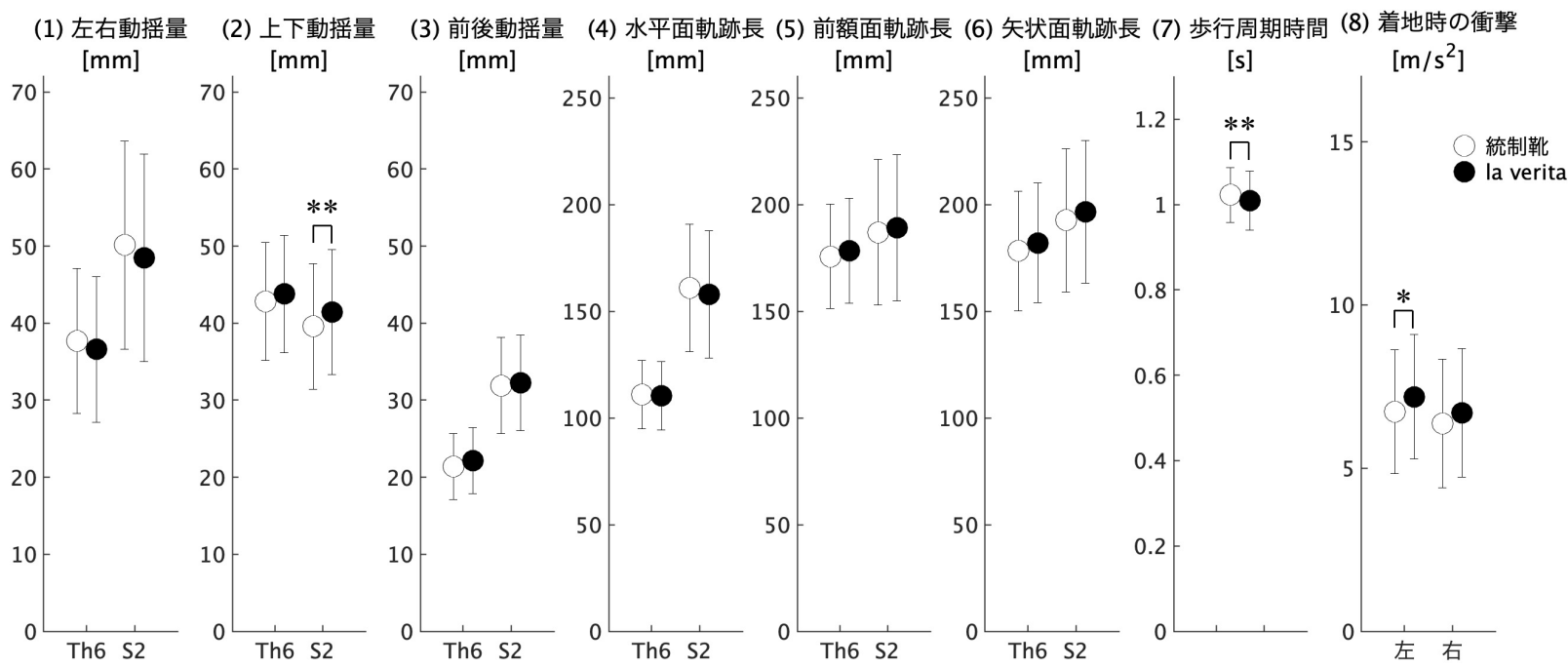

図2 各分析項目についての平均值および標準偏差, * $p<.05, * * p<.01$



\section{4. 考察}

図1の通り，la veritaは靴底に歩行を補助する加 工がされている.このアシストブルーバーは歩行 時の“踏切の良さ”の実現を期待して開発されたも のである。本実験結果において，統制靴条件と比 較し, la verita条件では上半身の上下方向に関連 する動きが大きかったことから，アシストブルー バーによる，靴底の“踏切の良さ”が，歩行を補助 した可能性があると考えられる．歩行中，足部は 踵から接地し，つま先側に重心が移動していき， 蹴り出し時につま先が離れる。この一連の動作が 円滑になることで，統制靴条件と比較しla verita 条件では相対的に足部が持ちあがりやすくなる. 足部が持ち上がることで，次の一歩が踏み出しや
(2) 前額面
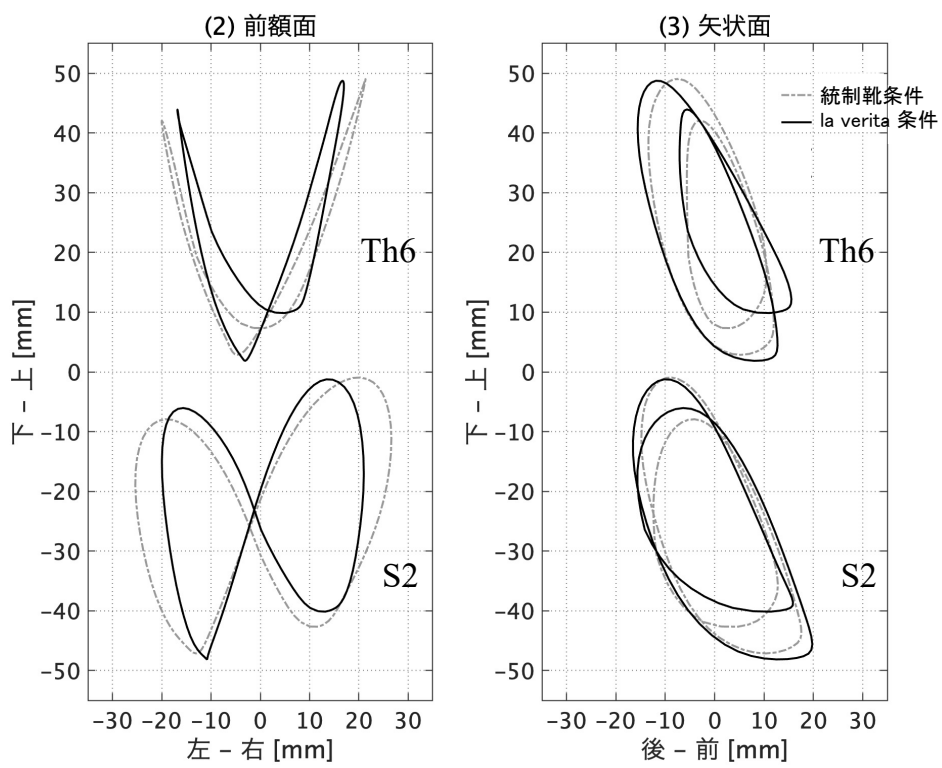

図3 軌跡図の典型例

すくなり，結果的に着地時の衝撃も大きくなった と考えられる。また，地面の蹴り出し時の動作が 円滑になることで，歩行のリズムが取りやすくな り，歩行周期時間が短くなったと考えられる.

有意な差は認められなかったが，統制靴条件と 比較し, la verita条件では左右動摇量が小さかっ た．歩行は姿勢を安定させながら前進する動作で ある. la verita条件では歩行中の推進力を得られ たことで左右の摇れが抑えられ，歩行の安定性に 寄与している可能性がある.

一方で，本研究では下肢の動作および歩行速度， 歩幅については計測がされていない.今後は体幹 の動作とともに，下肢の詳細な動作計測を行うこ とで，アシストブルーバーによる，歩行補助効果 についての発生機序を追求していく必要がある. 